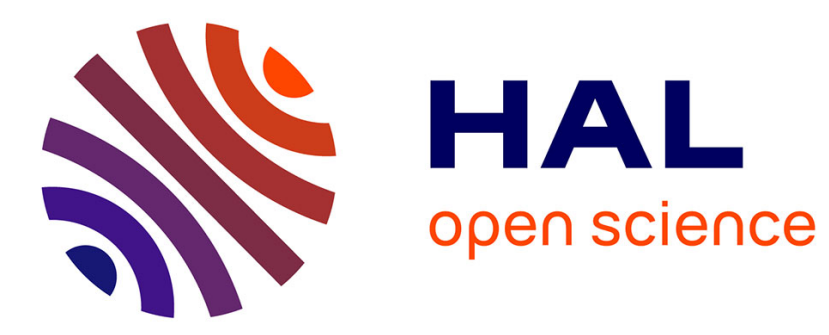

\title{
Potentially harmful elements in house dust from Estarreja, Portugal: characterization and genotoxicity of the bioaccessible fraction
}

Sophie Plumejeaud, Amelia Paula Reis, Virginie Tassistro, Carla Patinha, Yves Noack, Thierry Orsière

\section{To cite this version:}

Sophie Plumejeaud, Amelia Paula Reis, Virginie Tassistro, Carla Patinha, Yves Noack, et al.. Potentially harmful elements in house dust from Estarreja, Portugal: characterization and genotoxicity of the bioaccessible fraction. Environmental Geochemistry and Health, 2018, 40 (1), pp.127-144. 10.1007/s10653-016-9888-z . hal-01761544

\author{
HAL Id: hal-01761544 \\ https://hal.science/hal-01761544
}

Submitted on 5 Apr 2019

HAL is a multi-disciplinary open access archive for the deposit and dissemination of scientific research documents, whether they are published or not. The documents may come from teaching and research institutions in France or abroad, or from public or private research centers.
L'archive ouverte pluridisciplinaire HAL, est destinée au dépôt et à la diffusion de documents scientifiques de niveau recherche, publiés ou non, émanant des établissements d'enseignement et de recherche français ou étrangers, des laboratoires publics ou privés. 


\title{
Potentially harmful elements in house dust from Estarreja, Portugal: characterization and genotoxicity of the bioaccessible fraction
}

\author{
Sophie Plumejeaud • Amelia Paula Reis • Virginie Tassistro • \\ Carla Patinha $\cdot$ Yves Noack · Thierry Orsière
}

\begin{abstract}
Due to their behavioral characteristics, young children are vulnerable to the ingestion of indoor dust, often contaminated with chemicals that are potentially harmful. Exposure to potentially harmful elements (PHEs) is currently exacerbated by their widespread use in several industrial, agricultural, domestic and technological applications. PHEs cause adverse health effects on immune and nervous systems and can lead to cancer development via genotoxic mechanisms. The present study is an integrated approach that aims at assessing the genotoxicity of bioaccessible PHEs following ingestion of contaminated house dust. A multidisciplinary methodology associating chemical characterization of five house dust samples, extraction of the bioaccessible
\end{abstract}

S. Plumejeaud · V. Tassistro · T. Orsière $(\square)$ Institut Méditerranéen de Biodiversité et d'Ecologie marine et continentale (IMBE), Aix Marseille Université, CNRS, IRD, Avignon Université, Faculté de Médecine Timone, 27 Bd Jean Moulin, 13005, Marseille, France e-mail: thierry.orsiere@imbe.fr

\author{
A. P. Reis - C. Patinha \\ GEOBIOTEC, Departmento de Geociências, \\ Universidade de Aveiro, Campus Universitario de \\ Santiago, 3810-193 Aveiro, Portugal \\ Y. Noack \\ Aix Marseille Université, CNRS, CEREGE UM34, \\ 13545 Aix-en-Provence, France
}

PHEs in gastric extracts by the unified BARGE method, determination of the bioaccessible fraction and in vitro genotoxicity of gastric extracts in adenocarcinoma gastric human (AGS) cells was developed. The five gastric extracts induced dose-dependent genotoxicity in AGS cells. Copper (bioaccessible concentration up to $111 \mathrm{mg} / \mathrm{kg}$ ) was probably the prevalent PHE inducing primary DNA damage (up to 5.1-fold increase in tail DNA at $0.53 \mathrm{~g} / \mathrm{l}$ of gastric extract). Lead (bioaccessible concentration up to $245 \mathrm{mg} / \mathrm{kg}$ ) was the most prevalent PHE inducing chromosome-damaging effects ( $r=0.55 ; p<0.001$ for micronucleated cells induction). The association of principal component analysis and Spearman's correlations was decisive to understand the chromosome-damaging properties of the bioaccessible PHEs in AGS cells. This methodology could be used on a larger-scale study to provide useful information for science-based decision-making in regulatory policies, and a better estimation of human exposure and associated health risks.

Keywords House dust - Unified BARGE method · Bioaccessibility · Genotoxicity · Alkaline comet assay $\cdot$ Cytokinesis-block micronucleus assay

\section{Introduction}

It has been reported that trace elements such as cobalt (Co), copper $(\mathrm{Cu})$, chromium $(\mathrm{Cr})$, molybdenum (Mo), manganese (Mn) and zinc ( $\mathrm{Zn})$ are essential 
nutrients required for various biochemical and physiological functions in the human body (WHO 1996). For some, including $\mathrm{Cr}, \mathrm{Cu}$ and $\mathrm{Zn}$, there is a narrow range of concentrations between beneficial and adverse effects (Chang 1996; Lee et al. 2012). Other trace elements such as aluminum ( $\mathrm{Al})$, antimony $(\mathrm{Sb})$, arsenic (As), barium (Ba), cadmium (Cd), gallium $(\mathrm{Ga})$, lead $(\mathrm{Pb})$, nickel $(\mathrm{Ni})$, thallium $(\mathrm{Tl})$, tin $(\mathrm{Sn})$ and vanadium (V) have no established biological functions and are considered as potentially harmful to humans. These potentially harmful elements (PHEs) contribute to genotoxicity involving reactive oxygen species and/ or DNA repair inhibition, apoptosis and cancer development in mammals (Anetor et al. 2007; De Boeck et al. 2003; Denys et al. 2012; Gebel 1997; Lee et al. 2012).

Human exposure to environmental PHEs has risen dramatically as a result of an exponential increase in their use in several industrial, agricultural, domestic and technological applications (Tchounwou et al. 2012). Ingestion, inhalation and dermal absorption are the likely routes of exposure. Experimental lines of evidence suggest that soil/dust ingestion is the major source of human exposure to environmental PHEs contaminants (Davis and Mirick 2006; Reis et al. 2014). Furthermore, given the large amount of time, people spend indoors, either at home, school or workplace, and the potential health risks posed by contaminants in house dust raise additional concerns (Lin et al. 2015). Indeed, recent studies suggested that exposure to contaminated house dust may represent an increased human health risk compared to contaminated exterior soil (Ibanez et al. 2010; Niu et al. 2010). Ingestion of dust generally occurs through deliberate hand-to-mouth movements, or unintentionally by eating food that has dropped on the floor and particles that have adhered to skin (U.S. Environmental Protection Agency 2008). Young children ( $<6$ years old), while exploring their environment, are particularly vulnerable to this exposure pathway due to frequent hand-to-mouth and object-to-mouth habits (Mohmand et al. 2015; Reis et al. 2015; Tulve et al. 2002). Characterization of PHEs house dust by several measures (concentration, load and loading rate) has been used to document the presence and influence of metal sources (Rasmussen et al. 2013). Further, in the particular case of lead, Aung et al. (2004) have shown that house dust and soil ingestion can be the predominant routes of exposure among children.
While the intake dose (the amount of a chemical ingested by an individual) is the most commonly used measure of exposure in toxicity studies, the absorbed dose is the one causing the most, if not all, adverse effects on human health. In addition to the determination of PHE concentrations in dust, data relative to the PHEs bioavailability (fraction of an ingested chemical that is absorbed by the body) and/or bioaccessibility (fraction of the contaminant that is released from its solid matrix in the gastrointestinal tract and is therefore available for absorption by the body) are key information in human health risk assessment. Several protocols have been developed for the ingestion pathway to assess the bioavailability of a PHE from its bioaccessibility (Oomen et al. 2002). The Bioaccessibility Research Group of Europe (BARGE) has developed an in vitro test, the unified BARGE method (UBM), which mimics the solubilization process during digestion and thus allows estimating the bioaccessibility of PHEs in the solid phase (Denys et al. 2009; Wragg et al. 2011). The UBM is considered to be representative of the physiological conditions in the human gastrointestinal (GI) tract (Wragg et al. 2011).

Previous studies investigating oral bioaccessibility of house dust mainly focused on organic compounds (i.e., polycyclic aromatic carbons, phthalates esters) obtained after organic extraction (Kang et al. 2011, 2013; Maertens et al. 2008; Pohren et al. 2012; Wang et al. 2013a, b). They quantified the toxicity by evaluating the excess lifetime cancer risk and some assessed the in vitro cytotoxic and genotoxic potentials of organic extracts by using bacterial mutagenic assays such as the Ames test, SOS chromotest and Salmonella assay (Kang et al. 2013, 2011; Maertens et al. 2008; Pohren et al. 2012; Wang et al. 2013a, b). Likewise, the toxicity of PHEs from house dust has been investigated using either the evaluation of excess lifetime cancer risk or cytotoxicity tests (Chen et al. 2014; Deschamps et al. 2013; Granero and Domingo 2002; Kurt-Karakus 2012). However, the ingested dose was used as the relevant measure to assess the health risk and the oral bioavailability of the PHEs was not estimated. Notably, as far as we know, no study was published focusing on the genotoxicity of PHEs in house dust taking into account their oral bioavailability.

The relationships between biomarkers of exposure, levels of two PHEs (copper and manganese) in house 
dust and their bioaccessible fractions (BAF) were investigated in the Aveiro district (north of Portugal) (Reis et al. 2015). Reis et al. (2015) evidenced that manganese levels in toenails were associated with house dust manganese contents and this association was supported by the bioaccessibility estimates. In this study, dust containing PHEs were characterized in 19 houses located at various distances from the chemical complex of Estarreja (Reis et al. 2015). Large variations in PHEs levels were found in the different sampled house dust.

The present pilot study is about an integrated approach that aims at assessing the genotoxicity of the BAF of PHEs considering that the ingested dose following incidental ingestion of contaminated house dust usually overestimates the absorbed dose. PHEs were characterized using ICP-MS on dust samples and on their BAF obtained by the UBM. The cytogenotoxic potentials of these extracts were evaluated on adherent human adenocarcinoma gastric stomach (AGS) cells using the WST-1 assay for cytotoxicity, the alkaline comet assay for primary DNA lesions quantification, and the centromeric micronucleus assay for chromosome breakages and losses assessment. AGS cells were chosen as a relevant model to assess the toxicity of PHEs contained in gastric extracts. AGS cells were previously used to assess in vitro cytotoxicity and genotoxicity of drugs and nanoparticles that may be ingested by humans (AlamEscamilla et al. 2015; Botelho et al. 2014).

It is a detailed interdisciplinary study, performed on 5 houses dust sampled in the study of Reis et al. (2015) and carried out for purposes of methodology development. Our study does not envisage achieving further information on the diagnosis, spreading or prevention of disease in the studied area.

\section{Materials and methods}

Characterization of the study area

Estarreja is a small coastal city in Portugal close to the broad "Ria de Aveiro" lagoon, which is a protected "Natura 2000 net" area (Fig. 1). The coastal plain around the lagoon supports an intensive and diversified agriculture, but since 1950 the region is also known for the large industrial chemical complex of Estarreja (CCE). For many years, several of these industries dumped their solid residues (including ashes and dust with $\mathrm{As}, \mathrm{Pb}, \mathrm{Cu}, \mathrm{Zn}$ ) in an improvised park inside the CCE, albeit the proximity of the urban center of Estarreja is only $1 \mathrm{~km}$ away. Awareness on the pollution of the "Ria de Aveiro" and on its ecosystems started in the 1980s (Patinha et al. 2014). Since then, technological upgrades associated with remediation measures implemented by the industries have strongly reduced the environmental burden of the area. However, by its dimension and configuration, the CCE is still regarded as the major pollutant of the Aveiro district.

\section{Dust sampling}

To carry out the present study on the genotoxic potential of the house dust bioaccessible fractions, 5 out of 19 houses dust sampled by Reis et al. (2015) were selected to be representative of the various

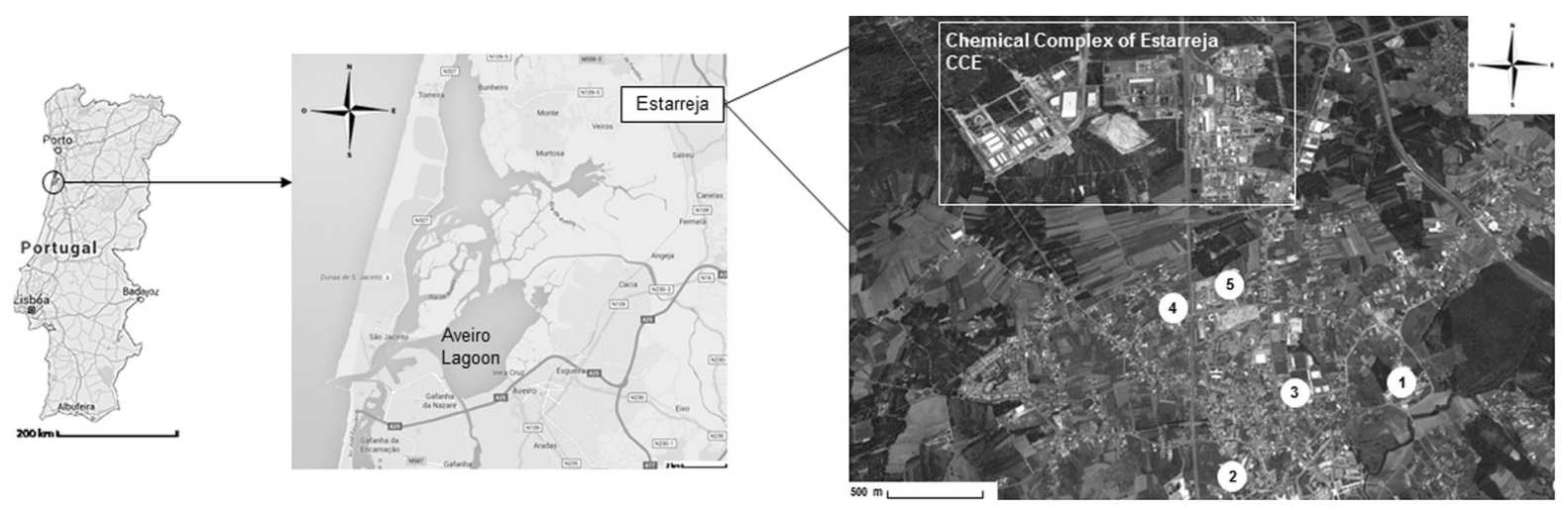

Fig. 1 Map of Estarreja showing the sampling sites, the CCE, and the location of Estarreja within the Aveiro district and Portugal 
sources of PHEs on Estarreja. Indeed, the five selected sites were far from each other (Fig. 1) compared to the geographical distribution of the sampled sites of Reis et al. (2015).

The floor surfaces were not cleaned for a period of 7 days before the scheduled house dust sampling. Composite house dust samples were collected from the floor and carpets using the high-volume small surface (HVS3) vacuum sampler, which is designed to capture $99 \%$ of the particles $\geq 0.5 \mu \mathrm{m}$ (Reis et al. 2015). Collected dust samples were oven-dried at $40{ }^{\circ} \mathrm{C}$ for $24 \mathrm{~h}$, sieved through a $150-\mu \mathrm{m}$ nylon mesh and stored in polyethylene containers at ambient temperature. The particle size $<150 \mu \mathrm{m}$ was chosen to the exploratory study because it represents the particle size range likely to adhere to hands and thus to be ingested following hand-to-mouth movements (Gron and Andersen 2003; U.S. Environmental Protection Agency 2000).

\section{Chemical analysis}

\section{House dust PHEs total concentrations}

Dust samples were digested in Aqua Regia at $90{ }^{\circ} \mathrm{C}$ in a microprocessor-controlled digestion block for $2 \mathrm{~h}$, and the analysis of 16 PHEs was carried out by inductively coupled plasma mass spectrometry (ICPMS) at the ACTLABS Analytical Laboratory, Canada. Each sample batch prepared for ICP-MS analysis included dust samples, duplicates and blanks. The Certified Reference Materials GRX-1, GRX-4, GRX6 and SAR-M (United States Geological Survey) were selected to represent a wide range of total elemental concentrations. The blanks results were always below detection limits. In this study, we focused on the 16 following PHEs: Al, Zn, Cu, Pb, Mn, Ba, Ni, Cr, Sn, V, $\mathrm{As}, \mathrm{Co}, \mathrm{Sb}, \mathrm{Mo}, \mathrm{Ga}$ and $\mathrm{Cd}$. Values for precision (expressed as RSD \%) are typically $<15 \%$ for all elements. Further information on QA/QC is provided as supplementary material (Table $\mathrm{S} 1$ ).

\section{Bioaccessibility of the PHEs in gastric extracts}

The bioaccessibility of the PHEs was determined by subjecting a small quantity of sample to the UBM. The UBM protocol consists of two parallel sequential extractions simulating the chemical processes occurring in the mouth, stomach and intestine compartments using synthetic digestive solutions according to physiological transit times, which allow us to obtain both gastric and gastrointestinal extractions (Denys et al. 2009). The methodology has been validated against a juvenile swine model for $\mathrm{As}, \mathrm{Cd}$ and $\mathrm{Pb}$ in soils, but not yet for less common PHEs (Denys et al. 2012). Several studies comparing in vivo bioavailability and in vitro bioaccessibility have shown that the in vitro gastric phase was generally closer to in vivo PHE concentrations (Wragg et al. 2011). Indeed, likely precipitation reactions attributed to basic $\mathrm{pH}$ solutions used in the gastrointestinal phase of the UBM protocol usually decrease the bioaccessibility estimates, which may underestimate the bioavailability of the PHEs.

The chemicals used in this experiment were provided by Sigma-Aldrich (Sintra, Portugal). For the gastric extraction, an aliquot of $0.6 \mathrm{~g}$ dust was extracted by $9 \mathrm{ml}$ of simulated saliva fluid (manually shaken) and $13.5 \mathrm{ml}$ of simulated gastric fluid. After adjusting the $\mathrm{pH}$ to $1.2 \pm 0.05$, the mixture was rotated at $37{ }^{\circ} \mathrm{C}$ for $1 \mathrm{~h}$ on an end-over-end shaker. After checking that the $\mathrm{pH}$ value was between 1.2 and 1.5 , the solution was centrifuged at $4500 \mathrm{rpm}$ for $15 \mathrm{~min}$, and then, the supernatant was removed and stored at $<4{ }^{\circ} \mathrm{C}$ for further analysis (Wragg et al. 2011).

The BAF corresponds to the ratio of PHE concentration in the gastric extract to total PHE concentration in dust and is expressed as percentage (Oomen et al. 2002):

BAF $\%=\frac{\text { PHE concentration in gastric extract }}{\text { PHE concentration in house dust }}$
$\quad \times 100$

The gastric extracts were analyzed by ICP-MS at CEREGE, France. Duplicate samples, the BGS 102 bioaccessibility reference material and blanks were extracted with every batch of UBM bioaccessibility extractions, for quality control purposes. The blanks always returned results that were below the detection limit.

Genotoxicity assays

Reagents

4'-6-Diamidino-2-phenylindole (DAPI), goat antihuman Alexa Fluor ${ }^{\circledR} 488$, trypsin $0.25 \%$ EDTA, fetal bovine serum (FBS) and PBS Dulbecco's were 
obtained from Life technologies (Saint Aubin, France). Paraformaldehyde (PAF) $4 \%$ PBS was from EMS (Hatfield, PA, USA). Bovine serum albumin (BSA) fraction $\mathrm{V}$ was purchased from Eurobio (Courtaboeuf, France). Vectashield was provided from Vector Laboratories (CA, USA). Human antikinetochore antibodies (CREST) were obtained from Laboratory of Immunology at the Hôpital de la Conception (Marseille, France). The other reagents were from Sigma-Aldrich (Lyon, France).

\section{Cells culture and cell viability assay}

Adherent human adenocarcinoma gastric stomach (AGS) cells were maintained in DMEM supplemented with $4.5 \mathrm{~g} / \mathrm{l}$ glucose, $2 \mathrm{mM}$ L-glutamine, $10 \% \mathrm{FBS}$, and $1 \%$ penicillin and streptomycin, at $37{ }^{\circ} \mathrm{C}$ under $5 \%$ of $\mathrm{CO}_{2}$. Cell Line Service (Eppelheim, Germany) provided all these reagents.

Cytotoxicity testing was performed by a colorimetric test, the WST-1 assay, to analyze the number of viable AGS cells by the cleavage of tetrazolium salts added to the culture medium. The choice of the concentration range to be tested was defined to approach the physiological gastric concentration of PHEs following dust ingestion by young children. As the ingestion rate of house dust by young children has been set by the INVS at $60 \mathrm{mg} / \mathrm{d}$ and the gastric volume of young children is about $500 \mathrm{ml}$, the PHEs physiological gastric concentration is estimated at $0.12 \mathrm{~g} / \mathrm{l}$ (INVS, Institut de Veille Sanitaire 2012).

AGS cells, grown in a 96-well plate at a density of $10^{5}$ cells/well, were incubated with gastric extracts at $0.067-0.13-0.27-0.53 \mathrm{~g} / \mathrm{l}$ and with the relative controls for 2 and $24 \mathrm{~h}$ before adding the WST-1 reagent. After 2-h incubation period, the formazan dye was quantified with a scanning multi-well spectrophotometer microplate reader (Multiskan, Thermo Scientific; Waltham, MA, USA) using a 450-nm emission filter. Three independent experiments were performed for each extract.

\section{Alkaline comet assay}

The alkaline comet assay was performed to evaluate primary DNA damage (Collins et al. 1993; Tice et al. 2000). Cells were seeded at a concentration of $2.5 \times 10^{4}$ cells/well in a 6-well plate; $24 \mathrm{~h}$ after the seeding, cells were exposed for $2 \mathrm{~h}$ to increasing concentrations of gastric extracts $(0.067-0.13-0.27-0.53 \mathrm{~g} / \mathrm{l})$ and vehicle control ( $2 \%$ gastric blank solution in DMEM), then trypsinized and pelleted. After dropping a layer of $0.8 \%$ NMP agarose in PBS onto SuperFrost ${ }^{\circledR}$ Microscope slides (Thermo Scientific; Braunschweig, Germany) pre-coated with $1.6 \%$ NMP agarose, the cellular pellets were resuspended in $1 \%$ LMP agarose and spotted onto the slides. Positive control was performed at this step by exposing AGS cells to $125 \mu \mathrm{M} \mathrm{H}_{2} \mathrm{O}_{2}$ for 5 min at $4{ }^{\circ} \mathrm{C}$. After cellular lysis ( $90 \mathrm{~min}$ at $4{ }^{\circ} \mathrm{C}$, in the dark) by using a freshly prepared lysis solution $(2.5 \mathrm{M} \mathrm{NaCl}, 100 \mathrm{mM}$ $\mathrm{Na}_{2}$ EDTA, $300 \mathrm{mM} \mathrm{NaOH}, 10 \mathrm{mM}$ Tris, $\mathrm{pH} 10$ supplemented with $10 \%$ DMSO and $1 \%$ Triton X-100), slides were immersed, for $20 \mathrm{~min}$ at $4{ }^{\circ} \mathrm{C}$ in the dark, in a denaturation solution $(300 \mathrm{mM} \mathrm{NaOH}$ and $1 \mathrm{mM}$ EDTA). Electrophoresis was carried out at $27 \mathrm{~V}$ and $300 \mathrm{~mA}$ for $20 \mathrm{~min}$ at $4{ }^{\circ} \mathrm{C}$. Then, the slides were rinsed with neutralization buffer (4 mM Tris, $\mathrm{pH} 7.5)$ and finally dehydrated few seconds in methanol.

To evaluate DNA damage ( $\%$ tail DNA), the slides were stained with propidium iodide and analyzed using a fluorescence microscope BX 60 (Olympus; Rungis, France) equipped with an appropriate filter combination and a black-and-white camera (Andor Luca S) and driven by Komet 6.0 software (Andor ${ }^{\text {TM }}$ Technology; Belfast, UK). For each experimental condition, 100 cells were analyzed, and the experiments were repeated tree times. Two slides were prepared per concentration and 50 cells per slide were analyzed. Results were expressed as mean of $n=2$ slides $\times 3$ independent experiments.

\section{Cytokinesis-block micronucleus (CBMN) assay in combination with centromere labeling}

The CBMN assay was performed according to the original method described by Fenech (Fenech 2007), with minor modifications for AGS cells, while centromere labeling was performed as described by González et al. (2011). Cells were seeded at a concentration of $2.5 \times 10^{4}$ cells/chamber in Lab$\mathrm{Tek}^{\mathrm{TM}}$ 4-Chamber Slide ${ }^{\mathrm{TM}}$ (Nuc International; Villebon-sur-Yvette, France) and cultured under standard conditions $\left(37{ }^{\circ} \mathrm{C}, 5 \% \mathrm{CO}_{2}\right)$. After 24 -h culture, slides were treated with increasing concentrations of gastric extracts $(0.067-0.13-0.27-0.53 \mathrm{~g} / \mathrm{l})$, vehicle control ( $2 \%$ gastric blank solution in DMEM), and appropriate clastogenic and aneugenic positive controls (10 ng/ml mitomycin C (MMC) and $25 \mathrm{nM}$ 
colchicine, respectively). At the end of the treatment $(24 \mathrm{~h})$, the medium was removed and replaced by fresh medium containing $3 \mu \mathrm{g} / \mathrm{ml}$ cytochalasin B to inhibit cell division after mitosis. Following 24-h incubation, the culture medium was further changed and, after 2-h incubation, cells were washed in PBS and fixed (4\% PAF). To discriminate chromosome losses and breakages, cells were incubated with CREST serum $(1: 1000$ in $1 \%$ BSA/PBS) for 30 min. Cells were washed in $0.5 \%$ Triton X-100/ PBS and incubated with secondary antibody Alexa Fluor $^{\circledR} 488$ goat antihuman (1:200 in $1 \%$ BSA/PBS) for $1 \mathrm{~h}$. Cells were then washed in $0.5 \%$ Triton $\mathrm{X}-100 / \mathrm{PBS}$ and incubated with a $0.06 \mu \mathrm{g} / \mathrm{ml}$ solution of phalloidin-TRITC (tetramethylrhodamine B isothiocyanate) for $30 \mathrm{~min}$ to stain the cytoplasm. After two washes in $0.5 \%$ Triton X-100/PBS, cells were incubated with a solution of 4'-6-diamidino-2phenylindole (DAPI, 1:50,000) for $10 \mathrm{~min}$ to stain the nuclei. Finally, the slides were mounted in Vectashield and stored in dark at $4{ }^{\circ} \mathrm{C}$ until analysis.

Micronuclei (MN) contained in binucleated cells were scored using a fluorescence microscope BX 60 (Olympus; Rungis, France) equipped with a blackand-white camera (Andor Luca S) and appropriate filters for DAPI, phalloidin-TRITC and Alexa Fluor ${ }^{\circledR}$ 488.

Before the analysis, we calculated the cytokinesisblock proliferation index on 500 cells to provide the average number of cell divisions completed by the cells, as previously described (Benameur et al. 2011; Kirsch-Volders et al. 2003). Micronucleus analysis data are expressed as a frequency of binucleated micronucleated (BNMN) cells per 1000 binucleated cells; scoring criteria were in accordance with those previously described (Fenech 2007). Taking advantage of the centromeric labeling, micronuclei containing whole chromosome(s) positively labeled (centromeric micronuclei cell, $\mathrm{C}+\mathrm{MN}$ ), and acentric chromosome fragments that are not stained due to the absence of centromere (acentromeric micronuclei, C - MN) was discriminated (González et al. 2011; Iarmarcovai et al. 2006; Mateuca et al. 2006; Natarajan et al. 1996). Two chambers were prepared per concentration, and micronuclei were counted for 1000 binucleated cells on each chamber. Results were expressed as mean of $n=2$ slides $\times 3$ independent experiments.
Statistical analysis

Results of cytotoxicity and genotoxicity were expressed as the mean value of three independent experiments \pm standard deviation (SD). Data were submitted to statistical evaluation using one-way ANOVA. GraphPad Prism 6 (GraphPad Software, Inc., La Jolla, USA) software was used to perform statistical analysis and to draw the graphics. The significance was compared to negative control (vehicle: $2 \%$ gastric blank solution in DMEM). Values were considered statistically significant starting from $p<0.05$.

Relationships between bioaccessible PHEs and chromosome damage were investigated using two complementary methods, principal component analysis (PCA) and correlation. Principal component analysis (PCA) is a mathematical technique adapted to quantitative variables that transforms $n$ possibly correlated variables into a (smaller) number of uncorrelated variables referred to as principal component (Jolliffe 2014; Reis et al. 2015). Moreover, Spearman's correlation is adapted to analyze nonlinear monotonic relationships (increasing or decreasing) between the observation's ranks of two defined characteristics (chemical composition and chromosome damage).

\section{Results}

House dust PHE concentrations

House dust samples collected from five selected houses in Estarreja were analyzed by ICP-MS to determine elemental concentrations (Table 1). The arithmetic means, geometric means and medians of all analyzed PHEs in the 5 studied dust samples were calculated. Table 1 shows values for the 16 PHEs under study and compares the PHE concentrations with those reported in the literature (Chattopadhyay et al. 2003; Chen et al. 2014; Deschamps et al. 2013; Kurt-Karakus 2012; Lisiewicz et al. 2000; Rasmussen et al. 2001). Further data on PHE concentrations in the full set of indoor dust samples collected from 19 private households in the city of Estarreja are provided in the form of supplementary material (Table S2).

In all sites, the major element was $\mathrm{Al}$, whose median concentration was $11,100 \mathrm{mg} / \mathrm{kg}$, followed by trace 


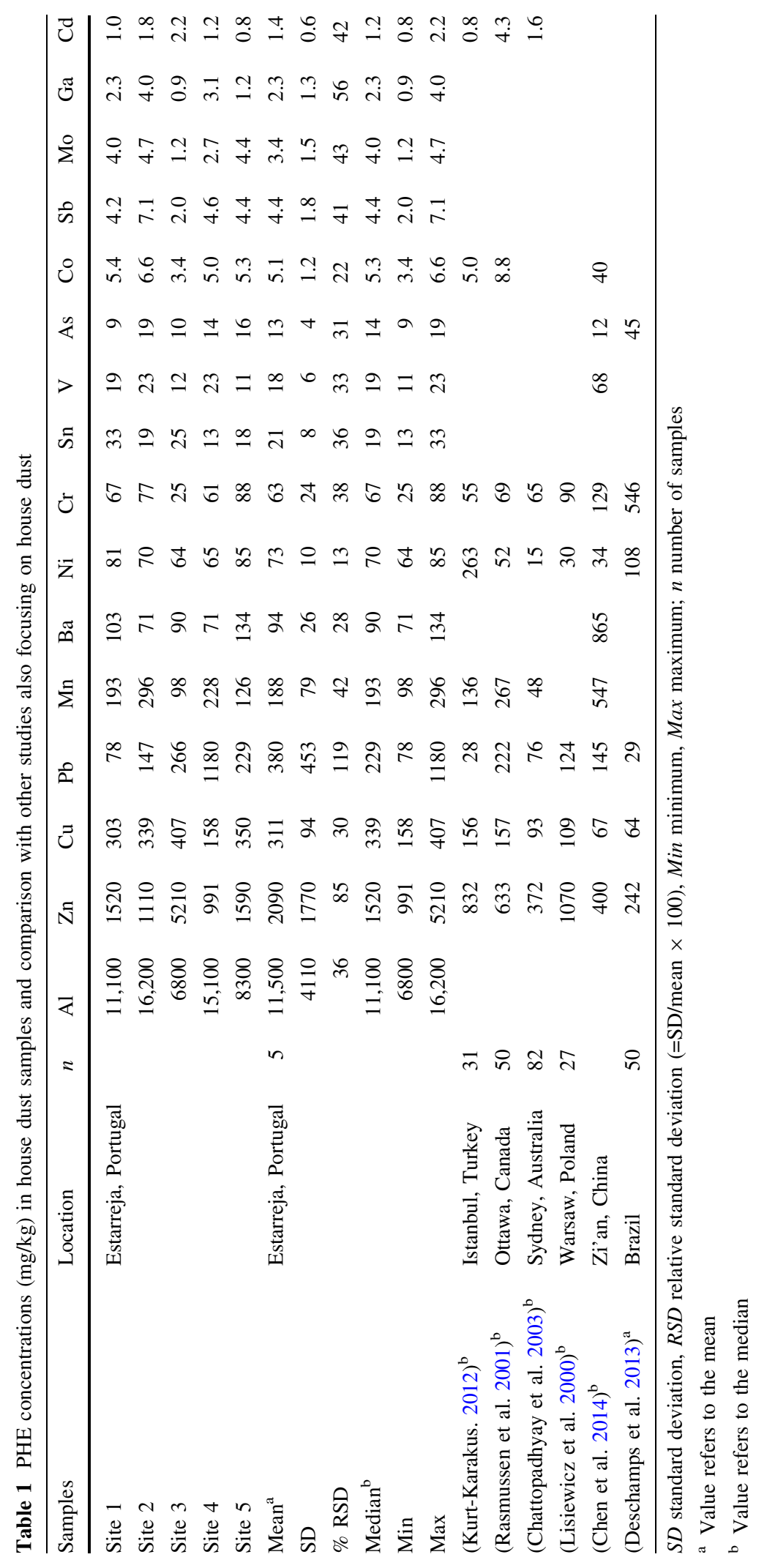


elements $\mathrm{Zn}, \mathrm{Cu}, \mathrm{Pb}, \mathrm{Mn}, \mathrm{Ba}, \mathrm{Ni}, \mathrm{Cr}, \mathrm{Sn}, \mathrm{V}$ and As. Co, $\mathrm{Sb}, \mathrm{Mo}, \mathrm{Ga}$ and $\mathrm{Cd}$ were the less abundant PHEs (median concentrations $\leq 5 \mathrm{mg} / \mathrm{kg}$ ). Notably, $\mathrm{Pb}$ $(78-1180 \mathrm{mg} / \mathrm{kg} ; \mathrm{RSD}=119 \%), \mathrm{Zn}(991-5210 \mathrm{mg} /$ $\mathrm{kg} ; \mathrm{RSD}=85 \%), \mathrm{Ga}(0.9-4.0 \mathrm{mg} / \mathrm{kg} ; \mathrm{RSD}=56 \%)$, Mo $(1.2-4.7 \mathrm{mg} / \mathrm{kg}$; RSD = $43 \%)$, Mn $(98-296 \mathrm{mg} /$ $\mathrm{kg} ; \quad \mathrm{RSD}=42 \%) \quad$ and $\mathrm{Cd} \quad(0.8-2.2 \mathrm{mg} / \mathrm{kg}$; $\mathrm{RSD}=42 \%$ ) showed a wide range of values, reflecting the heterogeneity of house dust chemistry among the five sites under investigation.

The Estarreja median levels for Zn $(1520 \mathrm{mg} / \mathrm{kg})$ and $\mathrm{Cu}(339 \mathrm{mg} / \mathrm{kg})$ were higher than the ones reported for other cities (Chattopadhyay et al. 2003; Chen et al. 2014; Deschamps et al. 2013; Kurt-Karakus 2012; Lisiewicz et al. 2000; Rasmussen et al. 2001). Pb median concentration in house dust from Estarreja was equivalent to that reported for Canadian house dust (Rasmussen et al. 2001), while it was nearly ten times higher than the ones from Turkey and Brazil (Deschamps et al. 2013; Kurt-Karakus 2012). Median levels of $\mathrm{Ni}, \mathrm{Cr}$, As and Co were similar to the majority of those reported in the literature (Chattopadhyay et al. 2003; Chen et al. 2014; Deschamps et al. 2013; KurtKarakus 2012; Lisiewicz et al. 2000; Rasmussen et al. 2001), whereas $\mathrm{Ba}$ and $\mathrm{V}$ were lower than the ones from China (Chattopadhyay et al. 2003; Chen et al. 2014; Deschamps et al. 2013; Kurt-Karakus 2012; Lisiewicz et al. 2000; Rasmussen et al. 2001).

\section{PHEs bioaccessibility in gastric extracts}

In the present study, the PHE concentrations extracted in the gastric phase were considered to be the relevant measure of exposure. Since our study focuses on the fate of the PHEs in the gastric compartment following incidental ingestion of house dust, bioaccessible PHEs were determined by using the UBM to mimic in vitro interactions between the dust and the gastric solutions (Table 2). Oral bioaccessibility data for the set of 19 samples are presented in supplementary material (Figure S1), while Table 2 shows the results obtained for the subset of 5 samples used in this study.

The BAF of the 16 studied PHEs ranged from 4 to $85 \%$ (Table 2), showing that some PHEs were highly bioaccessible, and others almost not. PHEs can be classified into three groups according to their bioaccessibility: first, $\mathrm{Zn}$ and $\mathrm{Cd}$ were highly bioaccessible (85 and $80 \%$, respectively); second, $\mathrm{Pb}, \mathrm{Mn}, \mathrm{As}, \mathrm{Ba}$, $\mathrm{Co}, \mathrm{Ni}, \mathrm{Ga}$ and $\mathrm{V}$ were moderately bioaccessible (from
62 to $41 \%$ ); and third $\mathrm{Cu}, \mathrm{Al}, \mathrm{Cr}, \mathrm{Sb}, \mathrm{Sn}$ and Mo were almost not available to humans (less than $27 \%$ ). Otherwise, bioaccessibility of $\mathrm{Sn}, \mathrm{Al}, \mathrm{Ba}$ and $\mathrm{Ga}$ was highly variable (RSD ranged from 64 to $54 \%$ ) from one house to another, suggesting variations in physicochemical forms, thus different PHE states of speciation. The overall assessment of the results (Table 2; Fig. S1) shows that the trends in the oral bioaccessibility of the PHEs are the same in the selected subset and in the broader set of samples subjected to the UBM protocol.

In the present study, the bioaccessibility of the 16 PHEs was considerably lower than the one reported for house dust in Turner and Simmonds (2006), which employed a simple surrogate (pepsin in $0.075 \mathrm{M} \mathrm{HCl}$ ) for the human stomach. They found that the bioaccessibility of $\mathrm{Al}, \mathrm{Cu}, \mathrm{Ni}$ and $\mathrm{Pb}$ averaged between 60 and $100 \%$ (Turner and Simmonds 2006), whereas our results were in accordance with those of Rasmussen (2004) reporting BAF of $30-40 \%$ for $\mathrm{Ni}$ and of $55-75 \%$ for $\mathrm{Pb}$ using $0.07 \mathrm{M} \mathrm{HCl}$ as extraction medium (Rasmussen 2004). These discrepancies between the reported results are likely related to the different protocols used. Differences in fluid formulation, $\mathrm{pH}$ values, residence time or type of shaking within the various in vitro tests can significantly affect the degree to which the PHEs are extracted from the soil/dust matrix (Oomen et al. 2002).

Results of the oral bioaccessibility testing indicate that a large proportion of the total $\mathrm{Cu}, \mathrm{Al}, \mathrm{Cr}, \mathrm{Sb}, \mathrm{Sn}$ and Mo content in the house dust were not in bioaccessible forms and are therefore unavailable to the residents via ingestion. Moreover, such low BAF values $(<30 \%)$ suggested that, in the dust, these PHEs were associated with resistant mineral phases that were hardly dissolved by the acidic solutions used in the gastric phase of the UBM protocol. In a previous study on these house dust that aimed at identifying likely environmental sources, Reis et al. (2015) suggested that $\mathrm{Cu}$ was probably related to waste materials of the CCE (Reis et al. 2015).

An overall analysis of the results obtained so far showed that the studied PHE concentrations were not elevated, although $\mathrm{Zn}, \mathrm{Pb}$ and $\mathrm{Cu}$ dust contents were above the ones reported in the literature (Table 1) (Chattopadhyay et al. 2003; Chen et al. 2014; Deschamps et al. 2013; Kurt-Karakus 2012; Lisiewicz et al. 2000; Rasmussen et al. 2001). While major fractions of $\mathrm{Cu}$ dust content were not available for 
Table 2 Bioaccessible PHE concentrations ( $\mathrm{mg} / \mathrm{kg}$ ) and PHEs bioaccessible fraction (BAF in \%) determined in the gastric extracts

\begin{tabular}{|c|c|c|c|c|c|c|c|c|c|c|c|c|c|c|c|c|}
\hline Samples & $\mathrm{Al}$ & $\mathrm{Zn}$ & $\mathrm{Cu}$ & $\mathrm{Pb}$ & $\mathrm{Mn}$ & $\mathrm{Ba}$ & $\mathrm{Ni}$ & $\mathrm{Cr}$ & $\mathrm{Sn}$ & V & As & Co & $\mathrm{Sb}$ & Mo & $\mathrm{Ga}$ & $\mathrm{Cd}$ \\
\hline \multirow[t]{2}{*}{ Site 1} & 2560 & 1260 & 82 & 52 & 98 & 45 & 32 & 16 & 3.8 & 6.4 & 3.6 & 2.0 & 0.5 & 0.2 & 0.8 & 0.7 \\
\hline & 23 & 83 & 27 & 67 & 51 & 43 & 39 & 23 & 12 & 34 & 40 & 37 & 12 & 4 & 35 & 69 \\
\hline \multirow[t]{2}{*}{ Site 2} & 2760 & 951 & 111 & 100 & 192 & 66 & 23 & 16 & 0.6 & 7.8 & 7.4 & 2.7 & 0.5 & 0.1 & 0.9 & 1.2 \\
\hline & 17 & 86 & 33 & 68 & 65 & 93 & 33 & 21 & 3 & 34 & 40 & 40 & 7 & 3 & 23 & 67 \\
\hline \multirow[t]{2}{*}{ Site 3} & 1070 & 4450 & 111 & 218 & 57 & 28 & 23 & 4.7 & 0.3 & 4.1 & 4.3 & 1.2 & 0.4 & 0.1 & 0.4 & 1.8 \\
\hline & 16 & 85 & 27 & 82 & 58 & 31 & 36 & 19 & 1 & 34 & 44 & 36 & 18 & 7 & 47 & 81 \\
\hline \multirow[t]{2}{*}{ Site 4} & 3110 & 658 & 58 & 245 & 157 & 49 & 21 & 9.8 & 1.2 & 11 & 8.3 & 2.1 & 0.5 & 0.1 & 1.1 & 0.9 \\
\hline & 21 & 66 & 37 & 21 & 69 & 70 & 33 & 16 & 9 & 48 & 59 & 41 & 11 & 3 & 35 & 80 \\
\hline \multirow[t]{2}{*}{ Site 5} & 4390 & 1440 & 46 & 165 & 81 & 29 & 35 & 15 & 1. 5 & 6.0 & 8.2 & 1.7 & 0.5 & 0.2 & 1.0 & 0.6 \\
\hline & 53 & 91 & 13 & 72 & 64 & 22 & 41 & 18 & 8 & 55 & 52 & 31 & 11 & 4 & 86 & 83 \\
\hline \multirow[t]{2}{*}{ Mean } & 2780 & 1750 & 82 & 156 & 117 & 44 & 27 & 12 & 1.5 & 7.1 & 6.3 & 1.9 & 0.5 & 0.1 & 0.9 & 1.1 \\
\hline & 26 & 82 & 27 & 62 & 61 & 52 & 36 & 19 & 7 & 41 & 47 & 37 & 12 & 4 & 45 & 76 \\
\hline \multirow[t]{2}{*}{ SD } & 1190 & 1540 & 30 & 80 & 56 & 16 & 6.3 & 5.0 & 1.6 & 2.6 & 2.2 & 0.6 & 0.0 & 0.1 & 0.3 & 0.5 \\
\hline & 15 & 10 & 9.1 & 24 & 7.0 & 29 & 3.6 & 2.7 & 4.5 & 9.9 & 8.3 & 3.9 & 4.0 & 1.6 & 24.3 & 7.4 \\
\hline \multirow[t]{2}{*}{$\%$ RSD } & 43 & 88 & 36 & 51 & 48 & 36 & 23 & 41 & 106 & 36 & 36 & 29 & 8.9 & 55 & 30 & 44 \\
\hline & 59 & 12 & 34 & 38 & 12 & 56 & 10 & 14 & 64 & 24 & 18 & 11 & 33 & 41 & 54 & 10 \\
\hline \multirow[t]{2}{*}{ Median } & 2760 & 1260 & 82 & 165 & 98. & 45 & 23 & 16 & 1.2 & 6.4 & 7.4 & 2.0 & 0.5 & 0.1 & 0.9 & 1.0 \\
\hline & 21 & 85 & 27 & 68 & 64 & 43 & 36 & 19 & 8 & 34 & 44 & 37 & 11 & 4 & 35 & 80 \\
\hline \multirow[t]{2}{*}{ Min } & 1070 & 658 & 46 & 52 & 57 & 28 & 21 & 4.7 & 0.3 & 4.1 & 3.6 & 1.2 & 0.4 & 0.1 & 0.4 & 0.6 \\
\hline & 16 & 66 & 13 & 21 & 51 & 22 & 33 & 16 & 1 & 34 & 40 & 31 & 7 & 3 & 23 & 67 \\
\hline \multirow[t]{2}{*}{ Max } & 4390 & 4450 & 111 & 245 & 192 & 66 & 35 & 16 & 3.8 & 11 & 8.3 & 2.7 & 0.5 & 0.2 & 1.1 & 1.8 \\
\hline & 53 & 91 & 37 & 82 & 69 & 93 & 41 & 23 & 12 & 55 & 59 & 41 & 18 & 7 & 86 & 83 \\
\hline
\end{tabular}

Bold and italic: bioaccessible fraction (BAF)

$S D$ standard deviation, $R S D$ relative standard deviation (=SD/mean $\times 100)$, Min minimum, Max maximum

absorption in the digestive system, $\mathrm{Zn}$ was quite bioaccessible (Table 2). The biogeochemistry of $\mathrm{Cd}$, which is currently ranked seventh on the Priority List of Hazardous Substances by the Agency for Toxic Substances and Diseases Registry, was also noteworthy. Despite the low $\mathrm{Cd}$ concentrations in the house dust samples (Table 1), the averaged Cd BAF was $76 \%$, showing that $\mathrm{Cd}$ was greatly available for absorption to the body (Table 2).

Regardless of the average PHE levels in the house dust samples, investigation on the genotoxic potential of their BAF is a new way to determine hazards closely associated with health risks.

In vitro cytotoxicity

The in vitro cytotoxicity of bioaccessible PHEs was assessed in AGS cells by using concentrations ranging from 0.067 to $0.53 \mathrm{~g} / \mathrm{l}$, surrounding the estimated physiological gastric concentration of $0.12 \mathrm{~g} / \mathrm{l}$ (Fig. 2).

Except for the highest tested concentration $(0.53 \mathrm{~g} /$ 1), the percentage of AGS cells viability was not statistically different from the negative control after 2and 24-h exposure to the gastric extracts, and it always remained above $80 \%$.

These results showed that the chosen concentrations were not cytotoxic. These concentrations were thus used for the analysis of bioaccessible PHE genotoxic potentials by the alkaline comet and the cytokinesis-block micronucleus assay (CBMN) in combination with centromere labeling.

In vitro genotoxicity of gastric extracts from house dust

The in vitro genotoxicity of the gastric extracts was assessed in AGS cells using two complementary tests, 
Fig. 2 Viability of AGS cells exposed for 2 and $24 \mathrm{~h}$ to the gastric extracts. Mean $\pm \mathrm{SD}$ values $\%$ cell viability of three independent experiments were determined. Statistical analysis versus the negative control was performed by one-way ANOVA: $p<0.05$

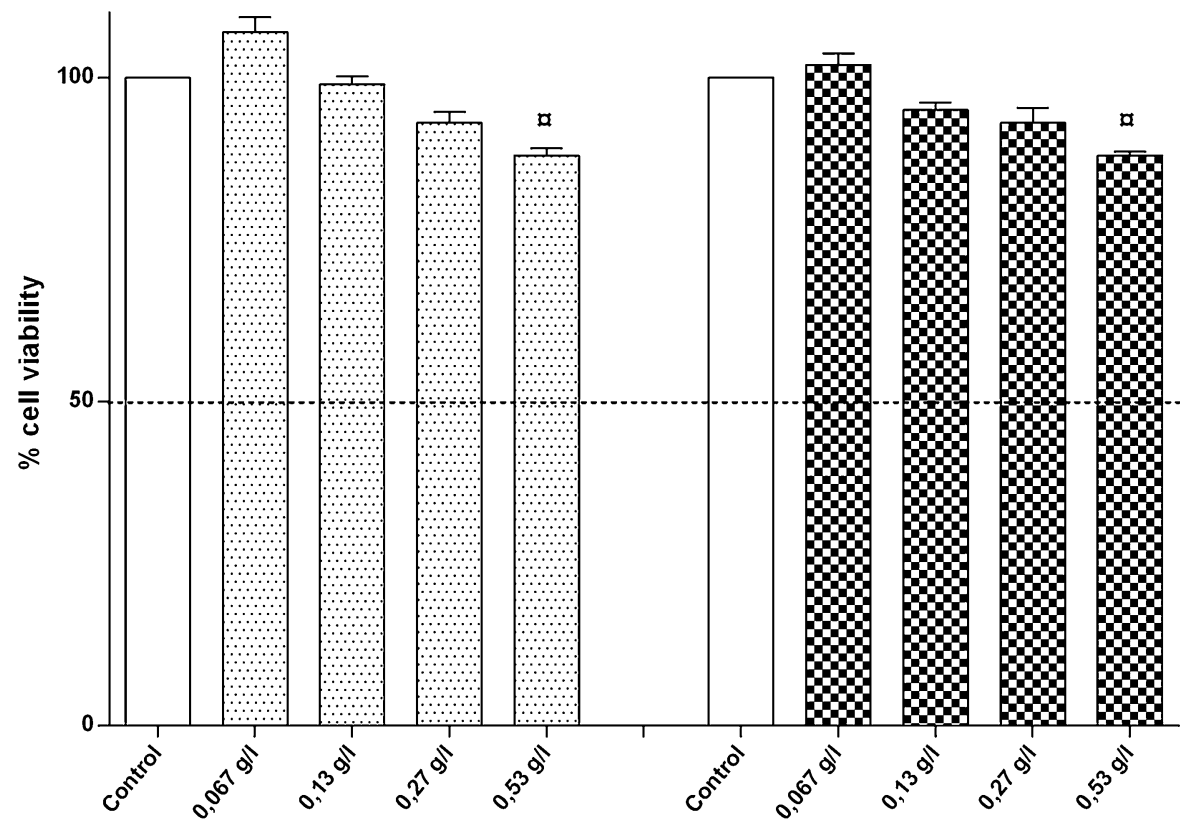

$2 \mathrm{~h}$ namely the alkaline comet assay, in order to assess the primary DNA lesions and the cytokinesis-block micronucleus (CBMN) in combination with centromere labeling assay in order to quantify chromosome breakages and losses induction.

\section{Alkaline comet assay}

DNA integrity of AGS cells exposed to the gastric extracts $(0.067-0.13-0.27-0.53 \mathrm{~g} / \mathrm{l})$ was evaluated at molecular level by the alkaline comet assay (Fig. 3), which allowed us to perform a quantification of singleand double-strand breaks, as well as alkali-labile and abasic sites formation (Collins et al. 2008).

A dose-dependent increase in the tail DNA content (\% tail DNA) was observed after 2-h exposure to the gastric extracts for all sites although no significant induction of primary DNA lesions was noted at $0.13 \mathrm{~g} /$ 1 for the site 4. Gastric extracts obtained from house dust of sites 1, 2 and 3 induced more severe primary DNA damage: the following exposure at $0.53 \mathrm{~g} / \mathrm{l}$, a 4.7-fold, 4.8-fold and 5.1-fold increase in DNA damage were observed, respectively. When AGS cells were exposed to the same concentration of gastric extracts obtained from house dust of sites 4 and 5, lower (3.0-fold and 3.3-fold, respectively) but still highly significant $(p<0.001)$ increases in primary DNA damage were noted.

The lowest tested concentration $(0.067 \mathrm{~g} / \mathrm{l})$ induced a highly significantly $(p<0.001)$ increase in primary DNA damage compared to negative control for sites 1 and 3 , a significant increase for sites 2 and $4(p<0.01$ and $p<0.05$, respectively), while nonsignificant DNA lesions were quantified for site 5 at this concentration. A significant increase $(p<0.01)$ relative to the negative control was observed for $0.27 \mathrm{~g} / \mathrm{l}$ for site 4 , and for the same site, the only highly significant $(p<0.001)$ induction of primary DNA lesions was measured at $0.53 \mathrm{~g} / \mathrm{l}$.

Hereafter, the experimental data show that all gastric extracts induced primary DNA lesions although the induction observed for sites 1, 2 and 3 were higher than those noted for sites 4 and 5 .

\section{Cytokinesis-block micronucleus assay (CBMN) in combination with centromere labeling}

Genome integrity was evaluated in vitro at chromosomal level by the CBMN assay (Fig. 4), a test that determines the frequency of micronuclei formation in exposed AGS cells and the CBMN assay was performed in combination with centromere labeling, 


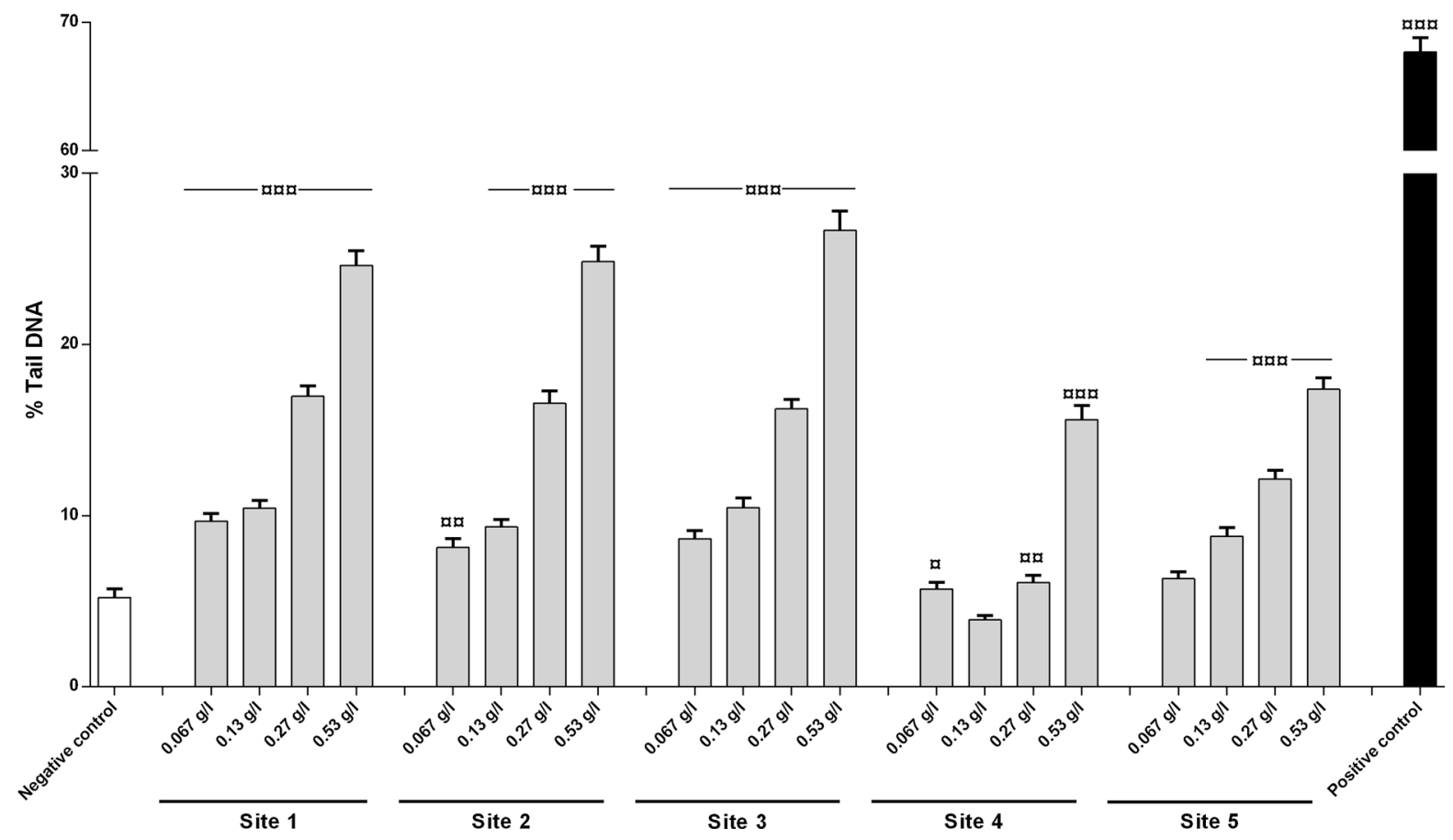

Fig. 3 Primary DNA damage investigated by alkaline comet assay in AGS cells exposed for $2 \mathrm{~h}$ to gastric extracts. Mean $\pm \mathrm{SD} \%$ tail DNA of three independent experiments

was determined. Statistical analysis versus the negative control was performed by one-way ANOVA: ${ }^{\alpha} p<0.05 ;{ }^{\infty} p<0.01$; ${ }^{\infty 000} p<0.001$

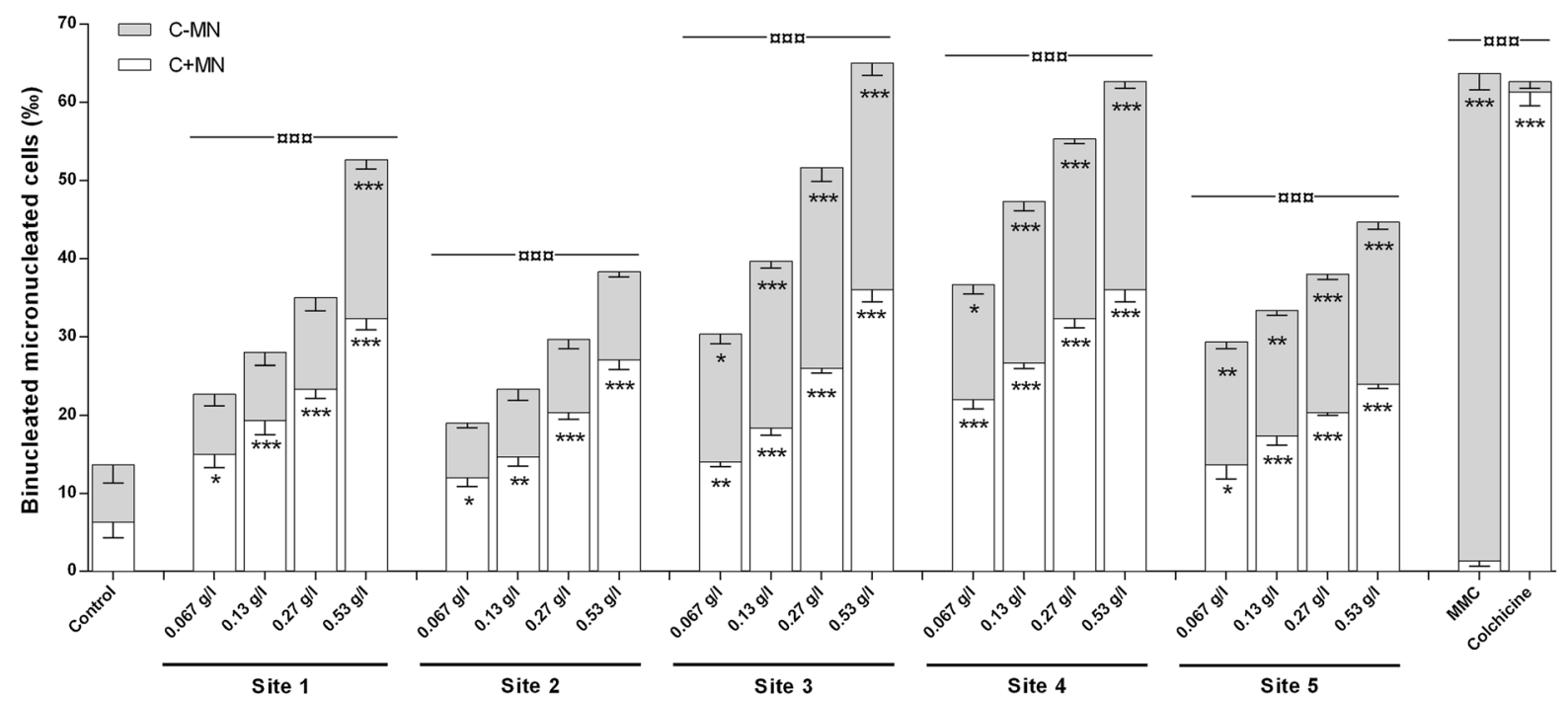

Fig. 4 Chromosome losses and breakages evidenced with CBMN assay in combination with centromere labeling in AGS cells exposed for $24 \mathrm{~h}$ to the gastric extracts. Frequency of $\mathrm{BNMN}$, mean $\pm \mathrm{SD}$ of $\mathrm{C}-\mathrm{MN}$ and $\mathrm{C}+\mathrm{MN}$ of three independent experiments were determined. Statistical analysis versus the negative control was performed by one-way ANOVA: ${ }^{\infty} p<0.001$ for BNMN and by two-way ANOVA: $* p<0.05 ; * * p<0.01 ; * * * p<0.001$ for $\mathrm{C}-\mathrm{MN}$ and $\mathrm{C}+\mathrm{MN}$ 
allowing the discrimination between breakages $(\mathrm{C}-\mathrm{MN})$ and losses $(\mathrm{C}+\mathrm{MN})$.

The frequency of binucleated micronucleated (BNMN) cells per 1000 binucleated AGS cells increased in a dose-dependent manner $(p<0.001)$ after $24 \mathrm{~h}$ of exposure to the gastric extracts from the 5 houses at all the tested concentrations (0.067$0.13-0.27-0.53 \mathrm{~g} / \mathrm{l})$. Gastric extracts corresponding to sites 3 and 4 induced more chromosome damage than those corresponding to sites 1,2 and 5 . At the highest tested concentration $(0.53 \mathrm{~g} / \mathrm{l})$, for sites 3 and 4, a 4.3-fold increase in chromosome damage was observed after 24-h exposure, while the frequency of BNMN increased up to 3.5-fold, 2.6-fold and 3.0-fold for sites 1, 2 and 5, respectively.

We further analyzed whether the BAF of the studied PHEs induced the formation of centromere positive $(\mathrm{C}+\mathrm{MN})$ or centromere negative micronuclei $(\mathrm{C}-\mathrm{MN})$ in AGS cells. Results showed that all gastric extracts induced dose-dependent increases in $\mathrm{C}+\mathrm{MN}$ in binucleated AGS cells after $24 \mathrm{~h}$, indicating an induction of aneugenic events such as chromosome migration abnormalities leading to chromosome losses. The highest in vitro aneugenic effect was noted for the gastric extract obtained from site 4 $(p<0.001)$.

Gastric extracts obtained from house dust induced dose-dependent $\mathrm{C}-\mathrm{MN}$ increases in binucleated AGS cells after 24-h exposure, indicating that clastogenic events (chromosome breakage, inducing a partial chromosome loss) occurred. For sites 1, except for the highest concentration $(0.53 \mathrm{~g} / \mathrm{l})$, and 2 , no significant induction of $\mathrm{C}-\mathrm{MN}$ was observed. The lowest concentration $(0.067 \mathrm{~g} / \mathrm{l})$ was significantly different from the negative control for sites 3 and 4 $(p<0.05)$, as well as for site $5(p<0.01)$. A statistically significant $(p<0.01)$ induction of $\mathrm{C}-\mathrm{MN}$ compared to the negative control was detected at $0.13 \mathrm{~g} / \mathrm{l}$ for site 5 , whereas this increase was highly significant $(p<0.001)$ for sites 3 and 4 . The highest in vitro clastogenic effect was noted for the gastric extract obtained from site 3 .

The highest in vitro chromosome damage was noted for the gastric extracts obtained from sites 3 and 4. The extracts from sites 3 and 4 were responsible for the most severe clastogenic and aneugenic effects, respectively. Finally, we observed that the gastric extracts from sites 3, 4 and 5 were efficient to induce chromosome breakages $(\mathrm{C}-\mathrm{MN})$ as well as chromosome losses $(\mathrm{C}+\mathrm{MN})$; conversely, the gastric extracts from sites 1 and 2 induced mostly chromosome losses.

\section{Multivariate analysis}

Principal components analysis (PCA) was performed to unravel possible relationships between bioaccessible PHEs in gastric extracts and their genotoxicity, in terms of chromosome damage (Fig. 5). The data matrix used to carry out the PCA was composed by the BAF of the 16 PHEs under study, in all sampled sites; in addition, $\mathrm{C}+\mathrm{MN}, \mathrm{C}-\mathrm{MN}$ and $\mathrm{BNMN}$ were projected as supplementary variables. The two first components, PC1 and PC2, accounted for
Fig. 5 Projections of the variables (PHEs) in the first factorial plane (PC1/PC2) of PCA analysis carried out for bioaccessible PHEs in gastric extracts of the five sites

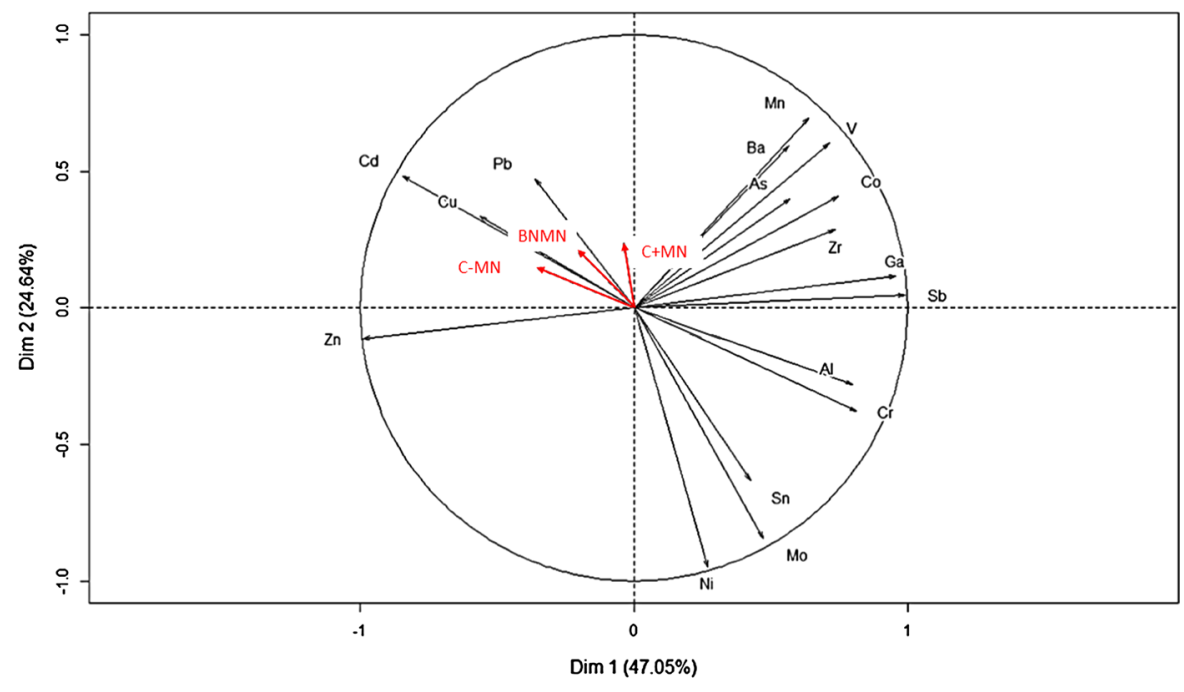


approximately $72 \%$ of the total variance of the dataset and were therefore selected to investigate geometrical relationships between the variables of interest.

The results showed that the chromosome damage (BNMN, C $+\mathrm{MN}$ and $\mathrm{C}-\mathrm{MN}$ ) was associated with a PHEs cluster composed by $\mathrm{Cd}-\mathrm{Cu}-\mathrm{Pb}$ and $\mathrm{Zn}$ to a certain extent (Fig. 5). Other clusters in the factorial plane were composed by $\mathrm{Ga}-\mathrm{Sb}$ and $\mathrm{Zr}-\mathrm{Co}-\mathrm{As}-\mathrm{V}-$ $\mathrm{Ba}-\mathrm{Mn}$, which were not related to chromosome damage. However, the diametric opposite projection of $\mathrm{Al}-\mathrm{Cr}$ relative to $\mathrm{Cd}-\mathrm{Cu}$ and $\mathrm{Ni}-\mathrm{Mo}-\mathrm{Sn}$ relative to $\mathrm{Pb}$ suggested that these elements were less abundant and, therefore, not involved in chromosome damage induction.

Spearman's correlation coefficients $(r)$ were calculated between chromosome damage $(\mathrm{C}+\mathrm{MN}$, $\mathrm{C}-\mathrm{MN}$ and $\mathrm{BNMN}$ ) and PHE concentrations in the gastric extracts to better support the interpretation of PCA results (Table 3).

$\mathrm{Pb}$ showed significant correlations with chromosome damage (BNMN: $p<0.001 ; r=0.55$ ), chromosome losses ( $\mathrm{C}+\mathrm{MN}: p<0.01 ; r=0.32)$ and chromosome breakage $(\mathrm{C}-\mathrm{MN}: \quad p<0.001 ; r=0.72)$ induced by gastric extracts in AGS cells. The induction of aneugenic events $(\mathrm{C}+\mathrm{MN})$ was also significantly correlated with $\mathrm{V}(p<0.05 ; r=0.28)$. Finally, $\mathrm{Zn}$ also induced significant clastogenic events $(p<0.01$; $r=0.34)$ in AGS cells. In addition, significant negative correlations were highlighted between PHEs and chromosome damage: (1) BNMN induction with $\mathrm{Ba}$ $(p<0.05 ; r=-0.27)$, Ni $(p<0.05 ; r=-0.28), \mathrm{Cr}$ $(p<0.001 ; \quad r=-0.50) \quad$ and Co $\quad(p<0.01$; $r=-0.35$ ); (2) $\mathrm{C}+\mathrm{MN}$ induction with $\mathrm{Ni}, \mathrm{Cr}$ and Mo $(r=-0.28, r=-0.31$ and $r=-0.33$, respectively, with $p<0.05$ ); and (3) $\mathrm{C}-\mathrm{MN}$ induction with $\mathrm{Cu}(p<0.05 ; r=-0.26), \mathrm{Mn}(p<0.01 ; r=-0.35)$, $\mathrm{Ba} \quad(p<0.001 ; \quad r=-0.49), \quad \mathrm{Cr} \quad(p<0.001$; $r=-0.62), \quad$ Co $\quad(p<0.001 ; \quad r=-0.56), \quad \mathrm{Sb}$ $(p<0.01 ; r=-0.38)$ and $\mathrm{Mo}(p<0.01 ; r=-0.46)$.

The joint interpretation of the results produced by the statistical tools used to investigate relationships between PHEs and genotoxic effects allows further detailing the effects detected in AGS cells exposed to the gastric extracts. While in Fig. $5 \mathrm{Cu}$ and $\mathrm{Cd}$ were projected associated with $\mathrm{BNMN}, \mathrm{C}+\mathrm{MN}$ and $\mathrm{C}-\mathrm{MN}$ inductions, the correlation coefficients were not statistically significant (Table 3 ). Thus, $\mathrm{Pb}$ appeared to be the PHE directly related to the observed chromosome damage. $\mathrm{Pb}$-induced clastogenic events seem to be prevalent over aneugenic events such as chromosome migration abnormalities leading to chromosome losses. Both PCA and Spearman's correlation highlighted a weak positive influence of $\mathrm{V}$ on
Table 3 Spearman's correlation coefficient and $p$ values between chromosome damage and bioaccessible PHE concentrations
Bold and italic: positive and significant (from $p<0.05$ ) correlation

$r$ Spearman's correlation coefficient

\begin{tabular}{|c|c|c|c|c|c|c|}
\hline & \multicolumn{2}{|l|}{ BNMN } & \multicolumn{2}{|l|}{$\mathrm{C}+\mathrm{MN}$} & \multicolumn{2}{|c|}{$\mathrm{C}-\mathrm{MN}$} \\
\hline & $r$ & $p$ value & $r$ & $p$ value & $r$ & $p$ value \\
\hline $\mathrm{Al}$ & -0.14 & $2.71 \mathrm{E}-01$ & -0.14 & $2.99 \mathrm{E}-01$ & -0.13 & $3.16 \mathrm{E}-01$ \\
\hline $\mathrm{Zn}$ & 0.18 & $1.77 \mathrm{E}-01$ & 0.00 & $9.84 \mathrm{E}-01$ & 0.34 & $7.07 E-03$ \\
\hline $\mathrm{Cu}$ & -0.20 & $1.27 \mathrm{E}-01$ & -0.12 & $3.73 \mathrm{E}-01$ & -0.26 & $4.63 \mathrm{E}-02$ \\
\hline $\mathrm{Pb}$ & 0.55 & $4.67 E-06$ & 0.32 & $1.23 E-02$ & 0.72 & $8.63 E-11$ \\
\hline $\mathrm{Mn}$ & -0.17 & $1.98 \mathrm{E}-01$ & 0.02 & $8.70 \mathrm{E}-01$ & -0.35 & $6.33 E-03$ \\
\hline $\mathrm{Ba}$ & -0.27 & $3.72 \mathrm{E}-02$ & -0.03 & $8.27 \mathrm{E}-01$ & -0.49 & $7.15 \mathrm{E}-05$ \\
\hline $\mathrm{Ni}$ & -0.28 & $3.29 \mathrm{E}-02$ & -0.28 & $2.91 \mathrm{E}-02$ & -0.23 & $7.93 \mathrm{E}-02$ \\
\hline $\mathrm{Cr}$ & -0.50 & $5.01 \mathrm{E}-05$ & -0.31 & $1.47 \mathrm{E}-02$ & -0.62 & $9.77 \mathrm{E}-08$ \\
\hline Sn & -0.15 & $2.64 \mathrm{E}-01$ & 0.01 & $9.54 \mathrm{E}-01$ & -0.29 & $2.41 \mathrm{E}-02$ \\
\hline V & 0.18 & $1.73 \mathrm{E}-01$ & 0.28 & $3.01 E-02$ & 0.04 & $7.50 \mathrm{E}-01$ \\
\hline As & 0.05 & $7.31 \mathrm{E}-01$ & $-1.74 \mathrm{E}-03$ & $9.89 \mathrm{E}-01$ & 0.09 & $4.97 \mathrm{E}-01$ \\
\hline Co & -0.35 & $6.20 \mathrm{E}-03$ & -0.10 & $4.25 \mathrm{E}-01$ & -0.56 & $3.05 \mathrm{E}-06$ \\
\hline $\mathrm{Sb}$ & -0.20 & $1.28 \mathrm{E}-01$ & -0.01 & $9.56 \mathrm{E}-01$ & -0.38 & $3.06 \mathrm{E}-03$ \\
\hline Mo & -0.42 & $8.36 \mathrm{E}-04$ & -0.33 & $1.08 \mathrm{E}-02$ & -0.46 & $2.35 \mathrm{E}-04$ \\
\hline $\mathrm{Ga}$ & -0.09 & $5.07 \mathrm{E}-01$ & 0.01 & $9.33 \mathrm{E}-01$ & -0.18 & $1.68 \mathrm{E}-01$ \\
\hline $\mathrm{Cd}$ & 0.14 & $2.85 \mathrm{E}-01$ & 0.05 & $6.98 \mathrm{E}-01$ & 0.22 & $9.78 \mathrm{E}-02$ \\
\hline
\end{tabular}


$\mathrm{C}+\mathrm{MN}$ induction and of $\mathrm{Zn}$ on $\mathrm{C}-\mathrm{MN}$ induction in AGS cells. Finally, the combination of the two methods shows few negative correlations: (1) BNMN induction with $\mathrm{Ni}$ and $\mathrm{Cr}$; (2) $\mathrm{C}+\mathrm{MN}$ induction with $\mathrm{Ni}$, Mo and $\mathrm{Cr}$ to a certain extent; and (3) C - MN induction with $\mathrm{Cr}$ and $\mathrm{Sb}$ to a certain extent.

\section{Discussion}

House settled dust is a mixture of displaced soil particles, outside airborne particles transferred by either wind, pets or shoes, and particles produced directly in the indoor environment (Glorennec et al. 2012). Hence, the chemical composition of house dust particles is influenced by both indoor and outdoor sources, which may partially explain the higher PHE contents usually found in indoor dust relative to exterior soil (Rasmussen et al. 2001; Reis et al. 2015). Thereupon, improvement of residential exposure assessments is achieved by dividing soil ingestion into separate categories for indoor house dust and exterior soil. In this study, exposure of a human adenocarcinoma gastric stomach cell line to gastric extracts obtained by unified BARGE method from house dust and assessment of the in vitro genotoxic potentials of these extracts at physiological concentrations aimed at establishing a novel methodology for human exposure assessment studies. The combination of bioaccessibility and genotoxicity evaluated by in vitro methods sequentially performed at physiological concentrations enables to assess the hazards relative to PHEs as close as possible to human exposure. The use of this methodology may be of uppermost importance, especially when the total PHE contents in the environmental media are close to the established regulatory screening values.

The cytotoxicity and genotoxicity assays of the gastric fractions extracted from house dust were carried out in AGS cells, a cell line representative of the cells exposed to the gastric liquid in humans. To avoid non-specific DNA fragmentation by necrosis and/or apoptosis under cytotoxic conditions, AGS cells were treated with gastric extracts concentrations inducing less than $20 \%$ cellular death. The genotoxicity was assessed with two complementary tests. The alkaline comet assay enabled the detection of singleand double-strand breaks directly produced or associated with incomplete excision repair processes, as well as alkali-labile sites (Collins et al. 2008; Karlsson et al. 2015). The CBMN assay with centromeric labeling (CREST antibodies) was suitable to determine in vitro chromosomal damage and to discriminate between clastogenic (chromosome breakage consecutive to protein DNA cross-links, interstrand cross-links and various DNA lesions occurring during the DNA replication) and aneugenic (chromosome loss consecutive to disruption of the mitotic apparatus) effects. Our data showed that the five tested extracts had dosedependent genotoxic properties in vitro.

In the five samples selected in our exploratory study, PHE dust contents were not elevated, although $\mathrm{Zn}, \mathrm{Pb}$ and $\mathrm{Cu}$ concentrations were above the ones reported in some recent studies (Table 1). However, the average $\mathrm{BAF}$ of $\mathrm{Cu}$ in the house dust samples under study was $27 \%$ (Table 2), which decreased the potential health risk posed by the element to the residents. Notably, the geometrical relationships between the PHEs of concern and the damages induced in AGS cells displayed in the PCA loadings plot suggested that chromosome damage (BNMN, $\mathrm{C}+\mathrm{MN}$ and $\mathrm{C}-\mathrm{MN}$ ) was largely associated with $\mathrm{Cd}, \mathrm{Cu}, \mathrm{Pb}$ and $\mathrm{Zn}$ to a certain extent (Fig. 5). While $\mathrm{Cu}$ was primarily not in bioaccessible forms and $\mathrm{Cd}$ contents were weak, $\mathrm{Pb}$ came forth as potential inducer of clastogenic effects $(\mathrm{C}-\mathrm{MN})$, aneugenic effects $(\mathrm{C}+\mathrm{MN})$ and global chromosome damage (BNMN). Also, to a certain extent, chromosome damage seemed to be influenced by $\mathrm{V}$ and $\mathrm{Zn}$ concentrations in the extracts for aneugenic and clastogenic effects, respectively.

The alkaline comet assay results indicated that the gastric extracts obtained from sites 1, 2 and 3 induced the most severe primary DNA damage, meaning that these samples affected more severely the DNA integrity of AGS cells. Sites 1, 2 and 3 presented the highest $\mathrm{Cu}$ concentrations in the gastric extracts, while no other PHE showed the highest concentrations in these three extracts. While dust $\mathrm{Cu}$ concentrations were elevated (Table 1), only a $27 \%$ fraction was on average solubilized by the gastric fluids, and the results achieved indicated that the bioaccessible $\mathrm{Cu}$ concentrations (Table 2) were likely related to primary DNA damage. It is well established in the literature that some PHEs, namely $\mathrm{Cu}$, may directly damage lipids, proteins and DNA due to their capacity to generate hydroxyl radicals, ROS production and oxidative DNA damage (Delfino et al. 2011). Further, 
lipid peroxidation products consecutive to the action of reactive oxygen species are well known to contribute to the formation of interstrand DNA cross-links and DNA-protein conjugates (Ayala et al. 2014). In these three sites (1, 2 and 3), the range of total $\mathrm{Cu}$ concentrations (303-407 mg/kg) was close or below the soil screening values for potentially unacceptable risk (residential soil use) provided by some EU countries (Carlon 2007).

The chromosome-damaging properties of the gastric extract were assessed by the use of the CBMN assay, and our results showed that the gastric extracts obtained from sites 3 and 4 induced the highest global chromosome damage (aneugenic and clastogenic effects) in AGS cells. Besides sites 3 and 4, the gastric extract from site 5 was also efficient to induce chromosome breakages $(\mathrm{C}-\mathrm{MN})$. These three house dust samples were the ones having the highest total and bioaccessible concentrations of $\mathrm{Pb}$. According to the literature, $\mathrm{Pb}$ is able to induce either clastogenic or aneugenic effects, suggesting a potential health risk in populations exposed to this PHE (Agency for Toxic Substances and Disease Registry (ATSDR) 2007; García-Lestón et al. 2010). Gastric extract from site 3, with the highest $\mathrm{Zn}$ concentrations, showed the most severe clastogenic effects, while the extracts from site 4, with the highest $\mathrm{V}$ concentrations, presented the most severe aneugenic effects. These results were also in accordance with the literature and the multivariate analysis results. $\mathrm{V}$ is found in different oxidation states, the most common being vanadium pentoxide is known to induce aneugenic events (Zhong et al. 1994). Concerning $\mathrm{Zn}$ exposure, even if at low concentrations, this PHE acts as a protector of genome stability, at concentrations higher than physiological ones, weak clastogenic effects were reported (Roney et al. 2006).

Finally, and as a first attempt to untangle the effects of exposure to a chemical mixture (represented by the UBM gastric extracts) in AGS cells, several interrelations can be highlighted. Although gastric extracts containing numerous elements were assessed, $\mathrm{Cu}$ is thought to be the prevalent PHE inducing primary DNA damage, while $\mathrm{Pb}$ was the most prevalent PHE inducing chromosome-damaging effects. While methodology development is the main purpose of this study, our results are in accordance with several recommendations (i.e., $\mathrm{Pb}$ ) and thus seem relevant to human health risk assessment considerations. Additionally, as clatogenic compounds are closely associated with an increased risk of carcinogenesis and as no threshold value can be established for direct DNA-damaging agents (a single mutation is still considered to be able to give rise to a clonal expansion and to a tumor), further investigations (in vivo studies) and preventive strategies and should be considered.

\section{Conclusions}

The pilot study described here proposes an interdisciplinary approach integrating environmental and health data derived from house dust samples collected from households of Estarreja. No similar study was found in the relevant literature, and the development of an integrated approach combining environmental and toxicity data was the primary endpoint of the present study. Thereby, our study did not envisaged achieving further information on the diagnosis, spreading or prevention of disease in the studied area.

The association of alkaline comet and CBMN assays proved to be effective tools to investigate both primary DNA lesions and chromosome damage induced by bioaccessible PHEs in environmental samples. In fact, our study demonstrates that a combination of in vitro methods representative of the bioaccessibility and the genotoxicity of environmental contaminants could be useful to document hazards relative to human exposure to complex mixture, taking into account the representativeness of the cellular model used and the physiological concentration to be tested. Moreover, the method associating CBMN assay and CREST anti-kinetochore antibody labeling for centromere detection allowed us to reveal the mechanism of action (clastogenic or aneugenic) of bioaccessible PHEs. Further, the use of the UBM and of these two in vitro genotoxicity assays can be performed in few weeks and are rather cheap (about $1000 €$ per site), compared to in vivo assays. The combined interpretation of the bioaccessible data and the genotoxicity results is well complemented by the association of two statistical methods (geometric: PCA and analytic: Spearman's correlations) that turned out to be decisive to understand the role and action mechanisms of the bioaccessible PHEs in a human cell model.

The option of selecting house dust samples with PHE concentrations in the range of the current EU soil screening values for potentially unacceptable risk, 
unraveled the potential of this methodology to provide further information that can be used for science-based decision-making in regulatory policies, such as deriving soil screening values that are currently lacking in Portugal. By developing this methodology in broader studies, encompassing larger areas and comprehensive datasets, we should be able to correlate house dust PHE concentrations with the physical environment of the house, as well as with exterior anthropogenic contributions. Establishing links between site characteristics, PHE concentrations and their speciation, bioaccessibility and genotoxicity is likely to provide an accurate characterization of sources, pathways and fate of environmental PHEs, enabling more effective assessment of human exposure and associated health risks.

Acknowledgments Funding for this research was provided by the Labex DRIIHM, Réseau des Observatoires HommesMillieux-Centre National de la Recherche Scientifique (ROHM-CNRS) and ECosystèmes COntinentaux et Risques EnVironnementaux (ECCOREV). This work has also been carried out thanks to the support of the A*MIDEX project "CREER" $\left(\mathrm{n}^{\circ}\right.$ ANR-11-IDEX-0001-02) funded by the "Investissements d'Avenir" French Government program, managed by the French National Research Agency (ANR). The authors want to express their gratitude to Jocelyne Pompili for her technical help, Kankoé Sallah for his statistical analysis performed, as well as Chiara Uboldi for her precious help to write this article.

\section{Compliance with ethical standards}

Conflict of interest The authors declare that they have no conflict of interest.

\section{References}

Agency for Toxic Substances and Disease Registry (ATSDR). (2007). Toxicological profile for lead.

Alam-Escamilla, D., Estrada-Muñiz, E., Solís-Villegas, E., Elizondo, G., \& Vega, L. (2015). Genotoxic and cytostatic effects of 6-pentadecyl salicylic anacardic acid in transformed cell lines and peripheral blood mononuclear cells. Mutation Research-Genetic Toxicology and Environmental Mutagenesis, 777, 43-53. doi:10.1016/j.mrgentox. 2014.11.008.

Anetor, J. I., Wanibuchi, H., \& Fukushima, S. (2007). Arsenic exposure and its health effects and risk of cancer in developing countries: Micronutrients as host defence. Asian Pacific Journal of Cancer Prevention, 8, 13-23.

Aung, N. N., Yoshinaga, J., \& Takahashi, J. (2004). Exposure assessment of lead among Japanese children.
Environmental Health and Preventive Medicine, 9, 257-261. doi:10.1007/BF02898139.

Ayala, A., Muñoz, M. F., \& Argüelles, S. (2014). Lipid peroxidation: Production, metabolism, and signaling mechanisms of malondialdehyde and 4-hydroxy-2-nonenal. Oxidative Medicine and Cellular Longevity, 2014, 360438. doi:10.1155/2014/360438.

Benameur, L., Orsière, T., Rose, J., \& Botta, A. (2011). Detection of environmental clastogens and aneugens in human fibroblasts by cytokinesis-blocked micronucleus assay associated with immunofluorescent staining of CENP-A in micronuclei. Chemosphere, 84, 676-680. doi:10.1016/j.chemosphere.2011.03.027.

Botelho, M. C., Costa, C., Silva, S., Costa, S., Dhawan, A., Oliveira, P. A., et al. (2014). Effects of titanium dioxide nanoparticles in human gastric epithelial cells in vitro. Biomedicine and Pharmacotherapy, 68, 59-64. doi:10. 1016/j.biopha.2013.08.006.

Carlon, C. (Ed.) (2007). Derivation methods of soil screening values in Europe. A review and evaluation of national procedures towards harmonization. European Commission, Joint Research Centre, Ispra, EUR 22805-EN, 306 pp.

Chang, L. W. (1996). Toxicology of metals, volume I. CRC Press, Boca Raton, FL. https://www.crcpress.com/ Toxicology-of-Metals-Volume-I/Chang/p/book/97808737 18035.

Chattopadhyay, G., Lin, K. C.-P., \& Feitz, A. J. (2003). Household dust metal levels in the Sydney metropolitan area. Environmental Research, 93, 301-307. doi:10.1016/ S0013-9351(03)00058-6.

Chen, H., Lu, X., \& Li, L. Y. (2014). Spatial distribution and risk assessment of metals in dust based on samples from nursery and primary schools of Xi'an, China. Atmospheric Environment, 88, 172-182. doi:10.1016/j.atmosenv.2014.01.054.

Collins, A. R., Duthie, S. J., \& Dobson, V. L. (1993). Direct enzymic detection of endogenous oxidative base damage in human lymphocyte DNA. Carcinogenesis, 14, 1733-1735.

Collins, A. R., Oscoz, A. A., Brunborg, G., Gaivão, I., Giovannelli, L., Kruszewski, M., et al. (2008). The comet assay: Topical issues. Mutagenesis, 23, 143-151. doi:10. 1093/mutage/gem051.

Davis, S., \& Mirick, D. K. (2006). Soil ingestion in children and adults in the same family. Journal of Exposure Science and Environmental Epidemiology, 16, 63-75.

De Boeck, M., Kirsch-Volders, M., \& Lison, D. (2003). Cobalt and antimony: Genotoxicity and carcinogenicity. Mutation research/fundamental and molecular mechanisms of mutagenesis. Metals and Human Cancer, 533, 135-152. doi:10.1016/j.mrfmmm.2003.07.012.

Delfino, R. J., Staimer, N., \& Vaziri, N. D. (2011). Air pollution and circulating biomarkers of oxidative stress. Air Quality, Atmosphere and Health, 4, 37-52. doi:10.1007/s11869010-0095-2.

Denys, S., Caboche, J., Tack, K., Rychen, G., Wragg, J., Cave, M., et al. (2012). In vivo validation of the unified BARGE method to assess the bioaccessibility of arsenic, antimony, cadmium, and lead in soils. Environmental Science and Technology, 46, 6252-6260. doi:10.1021/es3006942.

Denys, S., Tack, K., Caboche, J., \& Delalain, P. (2009). Bioaccessibility, solid phase distribution, and speciation of 
$\mathrm{Sb}$ in soils and in digestive fluids. Chemosphere, 74, 711-716. doi:10.1016/j.chemosphere.2008.09.088.

Deschamps, E., Weidler, P. G., Friedrich, F., Weiss, C., \& Diabaté, S. (2013). Characterization of indoor dust from Brazil and evaluation of the cytotoxicity in A549 lung cells. Environmental Geochemistry and Health, 36, 225-233. doi:10.1007/s10653-013-9560-9.

Fenech, M. (2007). Cytokinesis-block micronucleus cytome assay. Nature Protocols, 2, 1084-1104. doi:10.1038/nprot. 2007.77

García-Lestón, J., Méndez, J., Pásaro, E., \& Laffon, B. (2010). Genotoxic effects of lead: An updated review. Environment International, 36, 623-636. doi:10.1016/j.envint. 2010.04.011.

Gebel, T. (1997). Arsenic and antimony: Comparative approach on mechanistic toxicology. Chemico-Biological Interactions, 107, 131-144. doi:10.1016/S0009-2797(97)00087-2.

Glorennec, P., Lucas, J.-P., Mandin, C., \& Le Bot, B. (2012). French children's exposure to metals via ingestion of indoor dust, outdoor playground dust and soil: Contamination data. Environment International, 45, 129-134. doi:10.1016/j.envint.2012.04.010.

González, N. V., Nikoloff, N., Soloneski, S., \& Larramendy, M. L. (2011). A combination of the cytokinesis-block micronucleus cytome assay and centromeric identification for evaluation of the genotoxicity of dicamba. Toxicology Letters, 207, 204-212. doi:10.1016/j.toxlet.2011.09.013.

Granero, S., \& Domingo, J. L. (2002). Levels of metals in soils of Alcalá de Henares, Spain. Human health risks. Environment International, 28, 159-164. doi:10.1016/S01604120(02)00024-7.

Gron, C., \& Andersen, L. (2003). Human bioaccessibility of heavy metals and PAH from soil. Danish Environmental Protection Agency (Environmental Project No. 840).

Iarmarcovai, G., Botta, A., \& Orsière, T. (2006). Number of centromeric signals in micronuclei and mechanisms of aneuploidy. Toxicology Letters, 166, 1-10. doi:10.1016/j. toxlet.2006.05.015.

Ibanez, Y., Le Bot, B., \& Glorennec, P. (2010). House-dust metal content and bioaccessibility: A review. European Journal of Mineralogv. 22. 629-637. doi:10.1127/0935-

Jolliffe, I. (2014). Principal component analysis. In Wiley StatsRef: Statistic Reference Online. John Wiley \& Sons, Ltd. doi:10.1002/9781118445112.stat06472.

Kang, Y., Cheung, K. C., \& Wong, M. H. (2011). Mutagenicity, genotoxicity and carcinogenic risk assessment of indoor dust from three major cities around the Pearl River Delta. Environment International, 37, 637-643. doi:10.1016/j. envint.2011.01.001.

Kang, Y., Yin, Y., Man, Y., Li, L., Zhang, Q., Zeng, L., et al. (2013). Bioaccessibility of polychlorinated biphenyls in workplace dust and its implication for risk assessment. Chemosphere, 93, 924-930. doi:10.1016/j.chemosphere. 2013.05.057.

Karlsson, H. L., Di Bucchianico, S., Collins, A. R., \& Dusinska, M. (2015). Can the comet assay be used reliably to detect nanoparticle-induced genotoxicity? Environmental and Molecular Mutagenesis, 56, 82-96. doi:10.1002/em.21933.

Kirsch-Volders, M., Sofuni, T., Aardema, M., Albertini, S., Eastmond, D., Fenech, M., et al. (2003). Report from the in vitro micronucleus assay working group. Mutation Research, 540, 153-163.

Kurt-Karakus, P. B. (2012). Determination of heavy metals in indoor dust from Istanbul, Turkey: Estimation of the health risk. Environment International, 50, 47-55. doi:10.1016/j. envint.2012.09.011.

Lee, J.-C., Son, Y.-O., Pratheeshkumar, P., \& Shi, X. (2012). Oxidative stress and metal carcinogenesis. Free Radical Biology and Medicine, 53, 742-757. doi:10.1016/j. freeradbiomed.2012.06.002.

Lin, Y., Fang, F., Wang, F., \& Xu, M. (2015). Pollution distribution and health risk assessment of heavy metals in indoor dust in Anhui rural, China. Environmental Monitoring and Assessment, 187, 4763. doi:10.1007/s10661-015-4763-4.

Lisiewicz, M., Heimburger, R., \& Golimowski, J. (2000). Granulometry and the content of toxic and potentially toxic elements in vacuum-cleaner collected, indoor dusts of the city of Warsaw. Science of the Total Environment, 263, 69-78. doi:10.1016/S0048-9697(00)00667-7.

Maertens, R. M., Yang, X., Zhu, J., Gagne, R. W., Douglas, G. R., \& White, P. A. (2008). Mutagenic and carcinogenic hazards of settled house dust I: Polycyclic aromatic hydrocarbon content and excess lifetime cancer risk from preschool exposure. Environmental Science and Technology, 42, 1747-1753. doi:10.1021/es702449c.

Mateuca, R., Lombaert, N., Aka, P. V., Decordier, I., \& KirschVolders, M. (2006). Chromosomal changes: Induction, detection methods and applicability in human biomonitoring. Biochimie, Facets of Environmental Nuclear Toxicology, 88, 1515-1531. doi:10.1016/j.biochi.2006.07.004.

Mohmand, J., Eqani, S. A. M. A. S., Fasola, M., Alamdar, A., Mustafa, I., Ali, N., et al. (2015). Human exposure to toxic metals via contaminated dust: Bio-accumulation trends and their potential risk estimation. Chemosphere, 132, 142-151. doi:10.1016/j.chemosphere.2015.03.004.

Natarajan, A. T., Boei, J. J., Darroudi, F., Van Diemen, P. C., Dulout, F., Hande, M. P., et al. (1996). Current cytogenetic methods for detecting exposure and effects of mutagens and carcinogens. Environmental Health Perspectives, 104, 445-448.

Niu, J., Rasmussen, P. E., Hassan, N. M., \& Vincent, R. (2010). Concentration distribution and bioaccessibility of trace elements in nano and fine urban airborne particulate matter: Influence of particle size. Water, Air, and Soil pollution, 213, 211-225. doi:10.1007/s11270-010-0379-z.

Oomen, A., Hack, A., Minekus, M., Zeijdner, E., Cornelis, C., Schoeters, G., et al. (2002). Comparison of five in vitro digestion models to study the bioaccessibility of soil contaminants. Environmental Science and Technology, 36, 3326-3334.

Patinha, C., Reis, A. P., Dias, A. C., Abduljelil, A. A., Noack, Y., Robert, S., et al. (2014). The mobility and human oral bioaccessibility of $\mathrm{Zn}$ and $\mathrm{Pb}$ in urban dusts of Estarreja ( $\mathrm{N}$ Portugal). Environmental Geochemistry and Health, 37, 115-131. doi:10.1007/s10653-014-9634-3.

Pohren, R. D. S., Rocha, J. A. V., Leal, K. A., \& Vargas, V. M. F. (2012). Soil mutagenicity as a strategy to evaluate 
environmental and health risks in a contaminated area. Environment International, 44, 40-52. doi:10.1016/j. envint.2012.01.008.

Rasmussen, P. (2004). Can metal concentrations in indoor dust be predicted from soil geochemistry? Canadian Journal of Analytical Sciences and Spectroscopy, 49, 166-174.

Rasmussen, P. E., Levesque, C., Chénier, M., Gardner, H. D., Jones-Otazo, H., Petrovic, S. (2013). Canadian house dust study: Population-based concentrations, loads and loading rates of arsenic, cadmium, chromium, copper, nickel, lead, and zinc inside urban homes. Science if the Total Environent, 443, 520-529. doi:10.1016/j.scitotenv.2012.11.003.

Rasmussen, P. E., Subramanian, K. S., \& Jessiman, B. J. (2001). A multi-element profile of house dust in relation to exterior dust and soils in the city of Ottawa, Canada. Science of the Total Environment, 267, 125-140. doi:10.1016/S00489697(00)00775-0.

Reis, A. P., Costa, S., Santos, I., Patinha, C., Noack, Y., Wragg, J., et al. (2015). Investigating relationships between biomarkers of exposure and environmental copper and manganese levels in house dusts from a Portuguese industrial city. Environmental Geochemistry and Health,. doi:10.1007/s10653-015-9724-x.

Reis, A. P., Patinha, C., Noack, Y., Robert, S., \& Dias, A. C. (2014). Assessing human exposure to aluminium, chromium and vanadium through outdoor dust ingestion in the Bassin Minier de Provence, France. Environmental Geochemistry and Health, 36, 303-317. doi:10.1007/s10653013-9564-5.

Roney, N., Osierb, M., Paikoff, S. J., Smith, C. V., Williamsa, M., \& de Rosa, C. T. (2006). ATSDR evaluation of the health effects of zinc and relevance to public health. Toxicology and Industrial Health, 22, 423-493.

Tchounwou, P. B., Yedjou, C. G., Patlolla, A. K., \& Sutton, D. J. (2012). Heavy metal toxicity and the environment. Experientia Supplementum, 101, 133-164. doi:10.1007/978-37643-8340-4_6.

Tice, R. R., Agurell, E., Anderson, D., Burlinson, B., Hartmann, A., Kobayashi, H., et al. (2000). Single cell gel/comet assay: Guidelines for in vitro and in vivo genetic toxicology testing. Environmental and Molecular Mutagenesis, 35, 206-221.

Tulve, N. S., Suggs, J. C., McCurdy, T., Cohen Hubal, E. A., \& Moya, J. (2002). Frequency of mouthing behavior in young children. Journal of Exposure Analysis and Environmental Epidemiology, 12, 259-264.

Turner, A., \& Simmonds, L. (2006). Elemental concentrations and metal bioaccessibility in UK household dust. Science of the Total Environment, 371, 74-81. doi:10.1016/j. scitotenv.2006.08.011.

U.S. Environmental Protection Agency. (2000). TRW recommendations for sampling analysis of soil at lead $(\mathrm{Pb})$ sites.

U.S. Environmental Protection Agency. (2008). Child-specific exposure factors handbook (No. EPA/600/R-06/096F). National Center for Environmental Assessment.

Wang, W., Wu, F.-Y., Huang, M.-J., Kang, Y., Cheung, K. C., \& Wong, M. H. (2013a). Size fraction effect on phthalate esters accumulation, bioaccessibility and in vitro cytotoxicity of indoor/outdoor dust, and risk assessment of human exposure. Journal of Hazardous Materials, 261, 753-762. doi:10.1016/j.jhazmat.2013.04.039.

Wang, W., Wu, F., Zheng, J., \& Wong, M. H. (2013b). Risk assessments of PAHs and $\mathrm{Hg}$ exposure via settled house dust and street dust, linking with their correlations in human hair. Journal of Hazardous Materials, 263(2), 627-637. doi:10.1016/j.jhazmat.2013.10.023.

WHO. (1996). Trace elements in human nutrition and health (No. 532). World Health Organization, Geneva, Switzerland.

Wragg, J., Cave, M., Basta, N., Brandon, E., Casteel, S., Denys, S., et al. (2011). An inter-laboratory trial of the unified BARGE bioaccessibility method for arsenic, cadmium and lead in soil. Science of the Total Environment, 409, 4016-4030. doi:10.1016/j.scitotenv.2011.05.019.

Zhong, B.-Z., Gu, Z.-W., Wallace, W. E., Whong, W.-Z., \& Ong, T. (1994). Genotoxicity of vanadium pentoxide in Chinese hamster V79 cells. Mutation Research/Genetic Toxicology, 321, 35-42. doi:10.1016/0165-1218(94)90118-X. 